\title{
Geo- and Ecocritical Considerations of Derek Walcott's Multitasking, Omnipresent Sea
}

\author{
Doris Hambuch \\ Dept. of English Literature; CHSS, United Arab Emirates University \\ P.O. Box 15551, Al Ain, U.A.E. \\ E-mail: hambuchd@uaeu.ac.ae; dhambuch@yahoo.com
}

Received: 20-04- 2015

Published: 01-11- 2015
Accepted: 25-07- 2015

doi:10.7575/aiac.ijalel.v.4n.6p.196
Advance Access Published: August 2015

URL: http://dx.doi.org/10.7575/aiac.ijalel.v.4n.6p.196

\begin{abstract}
This essay identifies four related functions regarding representations of the sea in Derek Walcott's poetry. Historical, communicative, and spiritual functions of the ocean trope appear to complement the overarching self-referential purpose throughout the massive oeuvre of the eighty-five year old St. Lucian Nobel Laureate. Despite Walcott's preoccupation with maritime and nautical imagery, this trope remains insufficiently studied. A more recent increase in attention owes to the two related critical approaches labeled eco- and geocriticism. Situating the former closer to the socalled humanities and the latter to the social - or natural sciences, this essay argues that they are equally relevant for the present study. Relying on Ben T. Jefferson's conclusion in "The Sea as Place in Derek Walcott's Poetry" (2013), that Walcott's representations of the sea favor phenomenological understanding as they challenge notions of nation, the focus is on the trope as active, driving force with its own agency.
\end{abstract}

Keywords: Caribbean literature; cultural geography; ecocriticism; geocriticism; poetry; Derek Walcott

\section{Introduction}

In Islandology: Geography, Rhetoric, Politics (2014), Marc Shell cautions that geographic determinism is "intellectually questionable and politically dangerous" (239). In agreement with this assessment, I contest Adam Kirsch's premise that a "poet who comes to consciousness on a small island [...] is doomed, or privileged, to spend a lifetime writing about the sea" (Kirsch 2014). Numerous poets, who grew up on small islands, including St. Lucia, do not share Derek Walcott's obsession with the ocean. I further disagree with Kirsch's claim that for Walcott the sea "can be anything, like matter itself." My goal in this essay is to identify in depth the many different roles the sea takes on throughout Walcott's poetry. This goal originates in the observation that the trope remains insufficiently discussed, although two related critical approaches appear to have more recently increased the attention paid to it: geo- and ecocriticism. Ben T. Jefferson provides the most extensive analysis of Walcott' representations of the sea in "The Sea as Place in Derek Walcott's Poetry" (2013). Building on Jefferson's conclusion that Walcott's representations of the sea favor phenomenological understanding as they challenge notions of nation, I will emphasize the active part the trope plays in Walcott's poems. With the help of illustrations from the many poetry collections Walcott published throughout his long life, I will identify four main functions of the poet's preoccupation with the sea. The most prominent is the selfreferential function for which the sea appears as storyteller, tale and listener. Closely related to it is the historical function, where the sea offers the sights simultaneously with their documentations. One may perceive it as a monument but also as the historian delivering its underlying facts, or the artist expressing them creatively. In a more intimate context, the sea occurs as participant in communications, and I therefore call this the communicative function. Finally, there is a spiritual function, which provides allusions to infinity and continuity.

Walcott's work is the subject of study in two separate anthologies dedicated to ecocriticism on the one hand, and geocriticism on the other. George B. Handley (2005) contributed an interview titled "The Argument of the Outboard Motor" to Caribbean Literature and the Environment: Between Nature and Culture, and Joanna Johnson's (2011) "Furrowing the Soil with His Pen: Derek Walcott's Topography of the English Countryside" appears in Geocritical Explorations: Space, Place, and Mapping in Literary and Cultural Studies. Neither of the two essays isolates representations of the sea. In the interview with Handley, however, Walcott makes an important statement that relates to the fourth, the spiritual function referred to in this essay: “. . the sea brings certainly more than a possibility; it brings the concept of a beginning, of another day, the beginning of a possibility of another kind of culture, another kind of civilization" (Handley 2005, 131). This statement may serve as illustration of the main difference I observe between the two related critical approaches. In general, ecocriticism seems more informed by disciplines within the realm of the socalled humanities, while geocriticism follows similar trajectories with a more social - or natural scientific orientation. Walcott's representations of the sea lend themselves to both these critical approaches concerned primarily with concepts of place and space. Jefferson's study serves as model in its combination of the two. Its questions appear equally informed by a philosophical as well as geographical background. As he carefully defines Walcott's rendering of the sea 
in relation to place on the one hand, and space on the other, he is bound to evaluate imbedded dangers to the seascape's sustainability.

The vernacular term for "both mother and sea" (Walcott 1990, 14) is included in the title of Walcott's epic poem Omeros. Seven Seas is the name of a major character in this text, and its closing phrase leaves no doubt about the weight Walcott's writing places on the aquatic part of our planet: “... the sea was still going on" (325). Numerous titles of shorter poems, from "A Sea Chantey," to "Missing the Sea," the subtitle "The Estranging Sea" of the closing chapter in Another Life, and "The Sea is History" testify to its significance beyond Omeros. Countless references, invocations and connotations throughout the entire oeuvre indeed justify its considerations as a leitmotif, and render it surprising that a recent anthology such as Interlocking Basins of a Globe (2013) does not list "sea," "ocean," or "the maritime" among the nineteen entries in the thematic index (Antoine-Dunne 282-4). Nor are they included in the inventory of entries with which they could most easily be associated: spatial contexts, the Caribbean and history, wandering, or Walcott and environmental values. In the following passages, I will illustrate and explain the four functions served by representations of the sea, before I return, in my conclusion, to their relevance for geo- and ecocritical approaches to Walcott's writing. I am thus not proposing to provide exclusively eco- or geocritical analyses, but rather that the practice of both approaches, which I consider more intricately linked than some of their proponents, has encouraged the kinds of analyses I do provide.

\section{The Self-referential Function}

Jefferson refers to Epitaph for the Young as Walcott's first major work (Jefferson 2013, 290), but the earlier self published collection 25 Poems includes the crucial text Glyn Maxwell selected as opening poem for The Poetry of Derek Walcott, 1948-2013. This text, which Maxwell titles after its first line "The Fishermen Rowing Homeward," already gives an excellent insight into the conceit, which treats the sea as the poet's craft itself. Collected Poems 19481984 features a slightly edited version of this text with the title "The Harbour" (Walcott 1986, 7), identifying it as one deemed worthy of inclusion in In a Green Night (1962), the first collection made available by a major publishing house. While the fishermen in the opening line are moving "homeward," the poet persona's progress is described as "outward,/On a sea which is crueler than any word/Of love." The poet's challenge is to be "Braving new water in an antique hoax." The young poet, who has carefully studied accessible predecessors, needs to find his/her place within the tradition, in order to make his/her original contribution to it at the given time and place. The figure of the rower, which Paula Burnett correctly identifies as "a key image" (Burnett 64) in Derek Walcott: Politics and Poetics (2000) gains prominence in Another Life, though Walcott really introduces it as early as the fourteen-liner "The Harbour," one of his first published poems.

The conceit of the sea as poetic craft, along with the rower attempting to navigate it, occurs more developed later in Walcott's writing career. The opening of his first long poem Another Life provides compelling evidence of this fact. Although it is exaggerated to call the text, as Jefferson does, "book-length autobiography and history of Saint Lucia" (295), the poem's purpose does relate to both these types of testimony. The opening lines of Another Life not only evoke the sea as the medium, they actually call it the book itself: "Verandahs, where the pages of the sea/are a book left open by an absent master/in the middle of another life -/I begin here again,/begin until this ocean's/a shut book..." (Walcott 1986, 145). Although Jefferson recognizes that the notion of an "'absent master' contains multiple meanings" (296), he fails to acknowledge the most obvious meaning, that of another artist, a poet as creator of so-called "masterpieces." The sea, which serves as means of transportation for the "antique hoax" in "The Harbour," now provides the surface on which to write new poetry. The image of the verandahs near the sea returns in the second to the last passage of Another Life, part III of chapter 23, where the speaker worries about the effects of tourism, construction and industrialization on the island, one of many passages which invite ecocritical inquiries. The sea, in this context, compares to the writing that remains preserved across time: "... when over the untroubled ocean, the moon/will always swing its lantern/and evening fold the pages of the sea,/and peer like my lost reader silently/between the turning leaves..." (Walcott 1986, 293). Closely related to the fourth function studied in this essay, the text here alludes to continuity. A poet's work may become preserved documentation of a certain life, in relation to another, or many others for that matter.

A similar reference to the common ground of timelessness appears in the preceding chapter 22, when the lyrical "I" prepares for the long text's conclusion by reflecting on its originality. This concern for the relationship between original ideas, unique ways to express them, and existing art surfaces as early as the vessel of an "antique hoax" seen sailing or gliding on "new water." It becomes more explicit with a statement such as, "So, I shall repeat myself, [...] as the sun repeats itself and the thundering waters//for what else is there/but books, books and the sea,/verandahs and the pages of the sea,..." (Walcott 1986, 489). To present the sea and diverse activities invested in it as his craft, certainly belongs to the conceits Walcott does repeat in ever so many original ways.

In association with the figure of the rower, who treats the sea as his poetic craft or material, Jefferson recognizes the formative symbolic value of the shipbuilding process in Epitaph for the Young:

Likening the process of forging a poetic voice to that of building a ship, especially the stage at which the ship is tested on the sea, indicates a deep, or even fundamental, bond between Walcott's poetry and the sea. The adverb "vaguely", through the intersection of the various languages that Walcott was proficient in or familiar with, also suggests nautical themes. Whilst the English "vague" suggests uncertainty, its Latinate root "vagus" means "to wander"; the French "vague" means a wave, and the Creole "vag" conflates both the English and the French meanings. In essence, this "vaguely" does not 
just mean uncertainly, it also suggests a journey that takes its movement, rhythms and qualities from

the sea. (291)

Jefferson's accurate interpretation scrutinizes lines from the second self-published collection, in which the poet persona echoes the conceit established in "The Harbour": "So, I began to write, to take up arms,/Fitting out vaguely for a pitiless sea,/Willing to drown under impersonal stars..." (290). While the sea is described as "cruel" in the earlier fourteenliner, it appears "pitiless" in this canto from Epitaph for the Young. The poet is not only well aware of the challenges ahead, he also wishes to emphasize this awareness in the context of his coming to terms with the tricky interplay between intentions, one's calling, and ways to manifest it. It may be worth reviewing, at this point, that Robert D. Hamner identifies Epitaph for the Young, with Walcott, as "Ur-text" for Another Life (Hamner 1993, 24), and the development of nautical metaphors is excellent evidence of this relation. Jefferson aptly uses the discussion of the shipbuilding process to refer to another poem, which unites the threats discussed in this passage. He reveals most manifestations of the "sea voice" in "The Schooner Flight", but stops short to recognize that the willingness to drown insinuated in Epitaph for the Young actually finds a radical consequence at the end of the three-decade older poem. "Shabine sang to you from the depths of the sea," is the closing line of "The Schooner Flight" (Walcott 1986, 361). The artist, who first fits out to commence a sea voyage, finally merges with the sea as place, geographically speaking, but also with his craft, seen metaphorically.

One possible connotation to a voice sounding from the depths of the sea shifts my discussion to the following segment of this essay, to considerations of the historical function. Many critics, including Burnett and Jefferson, have commented on Walcott's evocation of drowned slaves. To end "The Schooner Flight" with a location of the poet persona's own voice on the depths of the sea means to enforce the survival of a collective memory without historical records. The voices of drowned slaves, in other words, are conceivable even if they lack written or otherwise preserved documentation. It is easier to follow this argument when one considers Walcott's sense of cyclicality. Burnett provides maybe the simplest illustration of this concept through her interpretation of the rower rowing backward in about the middle of Another Life (Walcott 1986, 217). Reading the narrative poem alongside Shakespeare's Tempest and with reference to Joyce's vision of history as nightmare, Burnett concludes, "the rower in fact proceeds backwards into an unknown future, taking his bearings by his past" (Burnett 2000, 64). The following paragraphs focus on the significance of the sea with regard to different perspectives on history.

\section{The Historical Function}

The most obvious evidence of representations of the sea related to historical knowledge occurs in the poem with the explicit title "The Sea Is History." Initially included in The Star-Apple Kingdom (1979), this poem moves from the fictional storytelling at stake in my preceding section to the factual documentation typically ascribed to historians or political scientists. The poem opens with questions the origin of which Jefferson aptly identifies as people who are aware of their position of power (298): "Where are your monuments, your battles, martyrs?/Where is your tribal memory?" (CP 364). Addressing these people as "Sirs," the speaker answers, "in that grey vault. The sea. The sea has locked them up. The sea is History." To capitalize "History" means to emphasize its authoritative status, to treat it as the kind of records victors preserve and celebrate with monuments and other permanent symbols. Juxtaposing such culture with nature, and turning to the sea for alternative records, Walcott's poem suggests the recovery of details left out of authoritative documentation. It argues "for a critical engagement with hegemonic representational strategies" (262), as Birgit Neumann puts it in "Monumentalism and Monuments in Postcolonial Literatures: Dismembering Tradition." Recognizing the implications such critical engagement has for a more diverse discourse, Neumann writes that "the sea, according to [Walcott's] poem, brings the seemingly unconnected histories of diverse cultures into dynamic interaction and in so doing opens up a wide field of transcultural exchange and displacement" (263). The sea, which serves as bridge between continents on the earth's surface, is at the same time never consistent. The ocean, "a site of continuous transformation and renewal," in Neumann's words, "propels a kind of history that is always in the making and on the move." Such a concept of history rejects capitalization. It also, in a geocritical vein, encourages the zooming in on aspects of place, as it pushes those of time to the background.

Developing arguments made by Guy Rotella in Castings: Monuments and Monumentality in Poems by Elizabeth Bishop, Robert Lowell, James Merrill, Derek Walcott and Seamus Heaney (2004), Neumann enumerates many of the remarkable metaphors, which compare culturally constructed monuments or artifacts to elements of local submarine nature. These metaphors include "colonnades of coral" (Walcott 1986, 365), "gothic windows of sea-fans," and cathedrals in the shape of "groined caves" (366). They further include "mosaics/mantled by the benediction of the shark's shadow" (364), and the poem thus exemplifies or foreshadows the compelling definition Walcott provides of his craft in his Nobel Lecture: "Poetry, which is perfection's sweat but which must seem as fresh as the raindrops on the statue's brow, combines the natural and the marmoreal" (Walcott 1992). At the risk of stretching the sea connotation too far, it is worth recalling the water cycle and the origin of rain at this point. The "marmoreal", in any case, provides the tangible counterpart to the more versatile, transformative "natural", as official history combines tangible facts with less obvious author agendas and processes of selection. The dilemma is admittedly that humans experience nature exclusively through culturally conditioned perspectives. Handley summarizes this predicament as follows: "Nature signifies a difference from human history but because it is always emerging from traces of that history, it always presents itself in Barthesian terms as a thing made, or conceived, by the poet" (Handley 2000, 14). Walcott's sea, then, 
even in its most active state, necessarily remains the poet's creation. This fact, I argue, does not demean the impact of its agency in a reader's reception.

Rather than nature and culture, Walcott juxtaposes non-human with human nature in poem IX of the Midsummer collection: "Language never fits geography/except when the earth and summer lightening rhyme. [...] They never align, nature and your/own nature. Too rapid the lightening's shorthand,/too patient the sea repeatedly tearing up paper" (Walcott 1984, 19). The calendar year's cycle, from which this collection takes its title, corresponds to the poet's life cycle. In mid-life, little older than fifty, he is able to enumerate discoveries, part of his personal history so to speak, and simultaneously convey the daunting task to continuously express experiences related to them poetically. The discrepancy between language and geography, the artist's nature and his/her natural environment in the quotation presents the conviction that art represents, but can never be identical with reality. This conviction relates to the epigraph to the first book of Another Life. This book, titled "The Divided Child," begins with a quotation from André Malraux's Psychology of Art in which the emerging artist appears as the one more fascinated with artistic representations than with their objects (Walcott 1986, 143). Historical documentation, though not necessarily creative in the sense of artistic in its intention, certainly is also a form of reality representation.

"The Sea Is History" repeatedly and explicitly challenges definitions of "History." The stanzas following the fourth line, which repeats the title, "The Sea Is History," serve mainly to enforce the mocking tone of this statement. In the seventh stanza, the reader learns that "the ocean kept turning blank pages//looking for History" (Walcott 1986, 365). The end of stanza sixteen and the first line of stanza twenty-two underline that facts founded in faith are "not History" $(366,367)$. The closing line, referring to "History, really beginning" (367) suggests that one may account exclusively for facts in the tangible present. It manifests sentiments Walcott elaborates on in his essay, "The Muse of History" (1974). Neumann aptly paraphrases the main argument there to suggest that a so-called Western "emphasis on linear and teleological models is incompatible with the frequently cyclic mythography of non-Western cultures" (Neumann 2013, 269). A prominent proponent of linearity, as Neumann does not fail to point out, is the figure of Dennis Plunkett, the retired British major, in Omeros (270). Creative writing, according to Walcott's representation of Plunkett, along with other forms of creative expression, functions as alternative recording of given environments at specific times in specific places. One craft standing out besides writing and painting includes any activity involved in the production and post-production of fabric.

"... as the sea's lace dries in the sun," one reads toward the end of "The Sea Is History" (Walcott 1986, 366). The lace here may refer to parts of the sea such as its waves, but it may also turn the sea itself into a garment. The vision of the sea as fabric merges with the self-referential function discussed in the preceding segment of this essay in the beginning of Another Life: "And from a new book,/bound in sea-green linen, whose lines/matched the exhilaration which their reader,/rowing the air around him now, conveyed,/another life it seemed would start again" (149). It also merges with the spiritual function in an image presented in Omeros: “... Across the flecked sea/whose combers veil and unveil the rocks with their lace/the next port is Dakar" (Walcott 1992, 224). The conceit appears most stunning in the title poem of the collection, which also includes "The Sea Is History." Recalling once more the horrors of colonialism, "The StarApple Kingdom" tells of the Caribbean's birth as "an elliptical basin" (387) where "a people were absolved/of a history which they did not commit," and provides one of the most revealing passages for the pursuit of an ecocritical reading:

One morning the Caribbean was cut up

by seven prime ministers who bought the sea in bolts-

one thousand miles of aquamarine with lace trimmings,

one million yards of lime-coloured silk,

one mile of violet, leagues of cerulean satin-

who sold it at a markup to the conglomerates,

the same conglomerates who had rented the water spouts

for ninety-nine years in exchange for fifty ships,

who retailed it in turn to the ministers

with only one bank account, who then resold it

in ads for the Caribbean Economic Community,

till everyone owned a little piece of the sea,

from which some made saris, some made bandannas;

the rest was offered on trays to white cruise ships

taller than the post office; (390)

The sea here is not a garment but rather the raw material in a tailor shop. Its division according to capitalist principles accompanies the formation of individual countries in the quoted lines. The star apple, a tropical fruit common in the Caribbean region, exists in various shades ranging between purple, brown and yellow. Its choice as symbol of the individual countries may be inspired by the popularity of the star on another type of fabric, that of the flag. In the 
Caribbean, for example, the numbers of stars on the Dominican or the Grenadian flags indicate the number of parishes in the respective country. Hispanic Cuba and Suriname, the only Dutch possession to have gained independence, both sport the Lone Star on their flags. While the former's white star represents freedom and autonomy, the yellow version on Suriname's flag is said to symbolize the unity of all ethnic groups. Overall, these tangible signals of national identity give only very vague indications of the respective societies' values.

The above quoted lines condense the mechanisms of capitalist societies developed in the Caribbean during the Colonial Wars and accelerated in recent centuries. This acceleration attracts the kind of industrialization detrimental to natural landscapes, and my understanding of the term "landscape" includes the sea. The proportions of mentioned numbers, ninety-nine and fifty, to the "one bank account" recall capitalism's tendency to concentrate profits, while the idea that "everyone owned a little piece of the sea" indicates communal participation in the exploitation of natural resources. There is also an emphasis on the transcultural quality of the area's societies. While the saris refer to East Indian tradition, the bandannas are of African origin. It has become much easier to travel since the time of the Colonial Wars, and individuals as well as communities have become more mobile, partly as a result. Customs have always and continue to change, even with their practitioners anchored in the same place. Inventions as well as circumstances outside human control have always and continue to change the proverbial ways of the world. Certain traits and consequential developments in society, however, seem to remain the same. Walcott's representation of the sea often symbolize this fact, which I will further analyze in "The Spiritual Function." The sense of an eternal sea debated there relates to the historical function because something that is present throughout the ages should be best qualified as authority on historical documentation. As Walcott has it in the final book of Another Life, "You want to hear my history? Ask the sea." (Walcott 1986, 282). This personification of the sea as partner in conversation leads to the following segment on the communicative function.

\section{The Communicative Function}

Compared with the preceding functions discussed in this essay, there are much fewer examples to illustrate the ways in which the sea appears as active partner during interpersonal encounters. These few examples, however, should serve best to demonstrate the point at which I aim to take Jefferson's argument further, ever so slightly, to focus on the sea as a driving force. Considered from an anti-anthropocentric perspective more informed by ecocritical premises, the sea exhibits its own agency when it appears as correspondent, or as facilitator of very personal, even intimate meetings. The conceit of the sea as active partner relates to the idea that the poet persona at times locates himself within it, seen for example as someone who "sang to you from the depths of the sea" (Walcott 1986, 361). Although Jefferson correctly establishes that Walcott's "biocentricity" (Jefferson 2013, 289), or rather "ecocentricity" suggests, "human presence is not the sole criterion for defining place," his wording during relevant interpretations lacks the ultimate implication of the sea as animate force. In the context of "The Schooner Flight," Jefferson concludes, "the sea has become an integral part of [the speaker's] body" (291). I argue that the merging is reciprocal, that the sea as active partner receives Shabine, just as he appears to incorporate it. The following references to "Oceano Nox," Omeros, "Origins," "Islands" and "Coral" serve to defend this perception of Walcott's sea as an active entity with its own agency.

Throughout Walcott's work, the sea is one among several characters in a lively landscape. Its activities supersede common personifications in individual poems. This character's personality is transformative by nature. Described as "sly" in "The Harbour" (Walcott 1986, 7), it appears "soft" (345) as well as "dark" (358) and providing a "shining shield" (358) in "The Schooner Flight," or a "mirror" in the first poem of Midsummer (Walcott 1984, 11). As mentioned towards the end of the second section of this essay, the closing line of "The Schooner Flight" situates the poet persona Shabine within the sea, with his voice originating in the ocean's depths. One poem from The Arkansas Testament revolves around a sense of drowning. The title of this poem owes to a nineteenth-century text by Victor Hugo, in turn inspired possibly by a line from Virgil's Aeneid. "How many captains, how many sailors,/glad to set off toward some distant port/have vanished forever under this dark horizon!" Brooks Haxton translates the beginning of this poem by Hugo, who lost his own daughter in a boating accident (Haxton 2001, 22). Hugo's text revolves around the horrors of death by drowning. Echoing, to some extent, Walcott's conceit of the sea as book, Hugo's second stanza continues the interrogation: "How many coxswains with their gear/have hurricanes thrown into the waves - like pages/torn from books unread" (23). Whereas the sea itself provides the pages of a book not yet written in Walcott's Another Life, the drowning seafarers appear as pages in Hugo's “Oceano Nox." The fact that in Hugo's conceit, the book is "unread," recalls the unheard voices of drowned slaves discussed in the preceding segment of this essay. The mood in Hugo's poem remains as gloomy as the beginning leads to anticipate. Where "The Sea Is History" seeks to recover forgotten memory, Hugo's lines leave no such hope.

Walcott's "Oceano Nox," in contrast to Hugo's, celebrates the sea's stimulating qualities. In this poem, dedicated to fellow St. Lucian writer Robert Lee, the speaker mutters "the sea's lines, and they recede/to the emerald and ruby of a fading jet" (Walcott 1987, 53). The description of the night in this poem sounds festive. It inspires reflections on the local theater and music, as it pays tribute to African heritage. An audience's cheers and applause appear as "breakers flinging whitecaps into space" (55), and even if a nightmare was to follow such a night, "[t]he surf will smooth the sand's page" on the next day. The poem closes with the certainty that "a force/threshes the palms, lifting their hearts and yours" (55). The generally uplifting sentiment may be ascribed to considerations of the moon and the idea of a night that "whispers to the Ocean" (53), provoking a romantic atmosphere. The activity of the sea, which has created the muttered lines of a poet, is further emphasized through the movement of its surf. "[W]hat I read/sank in like surf reopening the wet/pores of sand..." the reader learns in the fifth stanza. The poem "Coral" evokes a similar image in an 
explicitly sexual context when a breast's "nipple rasps like sand,/Its pores, like [the lover's], shone with salt sweat" (Walcott 1986, 73). "Islands" likewise presents the sea in an intimate, erotic context, albeit in parenthesis: "(Your body stirring the creased sea/of crumpled sheets)" (52). While the sea takes the actual place of a lover in "Coral," it recalls the encounter's comfort as its facilitator in "Islands."

As it represents the power to unite and merge, the sea is also capable of separating. This fact becomes painfully clear in the choice of epigraph for the last book of Another Life. This book's title, "The Estranging Sea," hails from Matthew Arnold's "To Marguerite": "Who order'd that their longing's fire/Should be, as soon as kindled, cool'd?/Who renders vain their deep desire?-/A God, a God their severance ruled!/And bade betwixt their shores to be/The unplumb'd, salt, estranging sea" (Walcott 1986, 259). After the epigraph, the book begins with a tribute to Walcott's mentor, the painter Harry Simmons, and in preparing for the complete text's closure, it eventually returns to the image of the verandahs near the sea with which the long poem begins. Another Life ends with a homage to a fellow artist who also learned from Simmons, the painter Dunstan St. Omar. He receives the name "Gregorias" in the poem because "it echoes the blest thunders of the surf" (293). To present the surf's sound as blessed means to consider it fortunate. Unlike human lives, the sea is immortal as well as continuously transforming. The preceding canto juxtaposes the potential damage to the land, where "the hill's cut away for more tarmac,/the groves all sawn,/and bungalows proliferate on the scarred, hacked hillside" (292) with "the eternal summer sea." This sense of eternity, continuity, possibly associated with the liquid quality of the sea will be the focus of the following segment, "The Spiritual Function." In this context, the sea takes on the character of a wise counsellor whose advice builds on lessons from preceding ages. "Oceano Nox" addresses this function towards the end, after the night's festivities: "Oceano Nox. The clocks resume their motion,/a laser from the lighthouse skims a wave;/a different age is whispering to the ocean" (Walcott 1987, 54).

\section{The Spiritual Function}

A crucial conceit discussed in my introduction is that of the sea book left open by an absent master. In "The Selfreferential Function," I discuss similar passages throughout Walcott's poetry to elaborate on the implications of the sea as consistent element across centuries of human endeavor, in particular the writing of poetry. In "The Historical Function", I scrutinize representations of the sea at intersections between fact documentation and creative writing on the one hand, and between nature and culture or human nature on the other. Historical records aim to recover signs of past civilizations. A historical phase Walcott takes to task repeatedly is the time of the Colonial Wars. Since St. Lucia had to deal mainly with France and Britain during this time, eventually remained a British colony until its independence in 1979, the Empire in Walcott's poetry usually refers to Britain. In Midsummer, however, the poem XLIII divides into a series of seven sub-poems not arranged as cantos, in which "Empire" refers to the Spanish crown. The first one of these texts subtitled "Tropic Zone" names Cuba as location, where the ocean "is speaking another language" (Walcott 1984, 56). The sixth text in the series emphasizes the idea that though the sea persists, it is versatile: "The Empire sneers at all thoughts in the future tense./Only the shallows of the inland ocean mutter/lines from another sea, which this one resembles" (61). The notion of "another sea" may suggest another location, where citizens speak a different language, but also another time, in reference to the future tense mentioned in the preceding sentence. The first reading confirms Jefferson's conclusion that Walcott's focus on non-human life and place "reveals place as something that exists before imagined space" (Jefferson 2013, 302). This is a realization, which would be particularly relevant for geocritical inquiry.

The sea's eternal quality almost has the ring of an inhibition in poem XLV of Midsummer, the collection published in the poet's mid-life: "But, like time, the sea/can't turn over on its side to die like a gray empire/brought down by its own weight" (65). The decline of empires, related to their preceding exploitations of natural, among other resources, points towards ecocritical inquiry. Both these critical approaches, I argue, are equally useful for the present reading of Walcott's representations of the sea. This is partly due because, as I will explain, there is considerable overlap with regard to their premises. Beyond this overlap, however, ecocriticism's explicit sensitivity to environmental damage lends itself to analyses of numerous passages involving maritime metaphors in Walcott's work. With regard to geocriticism, it is the attention paid to differences between place and space, mapping and cartographic definitions that is beneficial for the understanding of Walcott's sea proposed throughout this essay. The latter is more predominant in Jefferson's study, though a combination is detectable, as stated in my introduction.

To portray the sea as driving force with its own agency, I argue in "The Communicative Function," encourages less anthropocentric, and by implication more ecocritical as well as geocritical readings of Walcott's work. The present segment of this essay follows the preceding three not because it is less important. On the contrary, although its manifestations occur generally less pronounced than the many instances of self-reflexive references to the sea, the discussion of this function can serve as a synthesis of threads spun throughout the essay.

Incidentally, maybe to symbolize the concept of cyclicality discussed in "The Historical Function" stylistically, Walcott also shows a preference for illustrations of what I call here the spiritual function towards the end of major texts. In the second to the last chapter of Another Life he writes that "over the untroubled ocean, the moon/will always swing its lantern/and evening fold the pages of the sea" (Walcott 1986, 293). The more voluminous Omeros ends with the following two lines: "A full moon shone like a slice of raw onion./When he left the beach the sea was still going on" (Walcott 1992, 325). The fact that the sea has such an omnipresent, multitasking part in Walcott' writing certainly suggests that it has been a major inspiration during the writing process. The idea that the fisherman ends a day's work at the end of Omeros can transform that the fisherman's life will eventually end, with the sea "still going on," even if it may be "another sea." Such indications of eternity or continuity also contain notions of the sea's vastness, and its 
mysteries. A poet will stop writing, but the sea continues to inspire new poetry. It is a place, a place also threatened by human activity, but not as visibly as the bordering land. In Walcott's conceits, it frequently plays the role of an immortal character with a mind of its own.

\section{Conclusion}

While most scholars situate the origins of ecocriticism in the 1970s, and one may trace its persistent popularity through the number of relevant publications, dedicated journals as well as associations, geocriticism has not yet made its mark in dictionaries of literary studies. Such oversight is surprising, especially because of its immediate global reach. Bertand Westphal's seminal Geocriticism: Real and Fictional Spaces $(2007 ; 2011)$ became available in English translation only a few years after the French Minuit published the original. Westphal, in turn, contributed the "Foreword" to his translator's own Geocritical Explorations: Space, Place, and Mapping in Literary and Cultural Studies (2011). Nevertheless, while the most recent Glossary of Literary Terms (2014) devotes four pages to an entry on "ecocriticism," it provides no entry at all on anything related to "geo-". The Abrams/Harpham treatment of the former concept is thorough, ending with many important references, from the Glotfelty/Fromm Reader (1996) to Garrard's more theoretical study (2004). Abrams and Harpham correctly point out that ecocritical studies have been diverse in theoretical perspective and procedure, but they also locate the common premise in the focus on landscapes and habitats, in short places, "with an acute awareness of the damage being wrought on that environment by human activities" (Abrams/Harpham 2014, 98). Although such a preoccupation with sustainability is not explicit in the theories of geocritcism, I argue that it does surface in their application, and this may well be due to the fact, that any current study of place cannot help but acknowledge certain threats any place is and has been exposed to.

When studying the mapping in "Star-Apple Kingdom," for example, it becomes obvious that the region's division into many countries, their competition over resources, and the growing dependence on the tourist industry inevitably create threats for the natural landscapes. An important step to account for such threats lies in a shift away from anthropocentric methodologies. This is precisely where I see the main overlap between the two critical approaches. In his foreword to Robert T. Tally Jr.'s Geocritical Explorations, Westphal emphasizes that geocriticism is "a geo-centered rather than ego-centered approach." It favors considerations of space and place rather than time, which renders Jefferson's study of Walcott's sea an excellent candidate for the category. In Geocriticism, however, Westphal lists ecocriticism along with imagology and geopoetics as literary approaches to space in order to differentiate his own theory in that it "places place at the center of the debate" (Westphal 112). To follow Jefferson's well founded rationale that Walcott "asserts that space has been written onto place" (Jefferson 2013, 289), should render Westphal's distinction problematic. My understanding is that both eco- and geocritcism revolve around place rather than space, focus on anti-anthropocentric inquiries, and aim for a more inclusive scope. Their main difference seems to be the foregrounding of sustainability concerns in the former, and the limits to representation in the latter. When Tally writes in his translator's preface to Westphal's Geocriticism that geocriticism allows "to explore how all ways of dealing with the world are somewhat literary" (Westphal 2011, x), he confirms the argument made in "The Historical Function," which centers around Walcott's line that "the sea is history."

My analyses of Walcott's representations of an omnipresent sea have shown that its overarching function is the one first discussed in the essay. I call it the self-referential function because it depicts the sea as storyteller, his/her medium, the book, its contents, the tales, and at times even the reader or listener. The communicative function refers to passages in which the sea appears as communication partner in a more personal, at times intimate context. The spiritual function, finally, revolves around a focus on the sea's persistence across time, as well as on its vastness. Ishion Hutchinson plays on this quality in a recent interview with Walcott, titled "A Voice at the Edge of the Sea," when he refers to Walcott's rhythm as reaching "oceanic magnanimity" (Hutchinson 2015). Walcott's sea takes on an immortal personality, which guarantees continuity in its most general sense. Because the sea occasionally appears in several of these functions simultaneously, I use the term "multitasking" in my title.

In the spirit of Walcott's stylistic cyclicality, since I opened this essay with a reference to Shell's Islandology, I will close it with another one. What is more, I wish to end with Islandology's beginning, the epigraph from Henry David Thoreau's Walden: "It is well to have some water in your neighborhood, to give buoyancy to and float the earth. One value of even the smallest well is that when you look into it you see that the earth is not continent but insular" (Shell 2014). My readings in this essay have shown that has not likely been a small well, which typically inspired Walcott's writing. A reader can easily detect the presence of an impressively large sea in many of his texts. As Jefferson describes this presence, Walcott's literature "seems to contain the Caribbean Sea within itself, and to originate from that Sea" (Jefferson 2013, 293). Building on Jefferson's study, my focus was on the sense of agency Walcott's sea displays.

\section{Sponsoring information}

The Research Council and Al Buraimi University College, the Sultanate of Oman.

\section{References}

Abrams, M. H. \& Harpham, G. (2014). A Glossary of Literary Terms. $11^{\text {th }}$ ed. Boston, MA: Cengage Learning. Antoine-Dunne, J. ed. (2013). Interlocking Basins of a Globe: Essays on Derek Walcott. Leeds: Peepal Tree Press.

Burnett, P. (2000). Derek Walcott: Poetics and Politics. Gainesville, FL: University Press of Florida. 
DeLoughrey, E. M. \& Gosson, R. K. \& Handley, G. B., eds. (2005). Caribbean Literature and the Environment: Between Nature and Culture. Charlottesville, VA: University of Virginia Press.

Hamner, R. D. (1993). Derek Walcott. New York: Twayne Publishers.

Handley, G. B. (2000). A Postcolonial Sense of Place and the Work of Derek Walcott. Interdisciplinary Studies in Literature and Environment, 7(2), 1-23.

---------, G. B. (2005). The Argument of the Outboard Motor': An Interview with Derek Walcott. Caribbean Literature and the Environment: Between Nature and Culture. Eds. Elizabeth M. DeLoughrey, Renée K. Gosson, and George B. Handley. Charlottesville, VA: University of Virginia Press. 127-39.

Haxton, B. (2001). Victor Hugo: Eleven Poems. The American Poetry Review (May/June): 21-28.

Hutchinson, I. (2015). A Voice at the Edge of the Sea: An Interview with Derek Walcott. Virginia Quarterly Review 91.1 Retrieved at http://www.vqronline.org/interviews-articles/2015/01/voice-edge-sea 12 January 2015.

Jefferson, B. T. (2013). The Sea as Place in Derek Walcott's Poetry. Journal of Commonwealth Literature, 48.2: 287304.

Johnson, J. (2011). "Furrowing the Soil with His Pen: Derek Walcott's Topography of the English Countryside." Geocritical Explorations: Space, Place, and Mapping in Literary and Cultural Studies. Ed. Robert T. Tally Jr. London/New York: Palgrave Macmillan. 161-176.

Kirsch, A. (2014). Full Fathom Five: Derek Walcott's Seascapes. The New Yorker 89.47. Retrieved at http://www.newyorker.com/magazine/2014/02/03/full-fathom-five-2 12 January 2015.

Maxwell, G. ed. (2014). The Poetry of Derek Walcott, 1948-2013. London: Faber and Faber.

Neumann, B. (2013). Monumentalism and Monuments in Postcolonial Literatures: Dismembering Tradition. Anglia, 131(2-3), 262-281.

Rotella, G. (2004). Castings: Monuments and Monumentality in Poems by Elizabeth Bishop, Robert Lowell, James Merrill, Derek Walcott, and Seamus Heaney. Nashville, TN: Vanderbilt University Press.

Shell, M. (2014). Islandology: Geography, Rhetoric, Politics. Stanford, CA: Stanford University Press.

Tally, R. T. Jr. ed. (2011). Geocritical Explorations: Space, Place, and Mapping in Literary and Cultural Studies. London/New York: Palgrave Macmillan.

Walcott, D. (2010). White Egrets. London: Faber and Faber.

---------, D. (1992). The Nobel Lecture - The Antilles: Fragments of Epic Memory. Retrieved at http://www.nobelprize.org/nobel_prizes/literature/laureates/1992/walcott-lecture.html 12 June 2015.

---------, D. (1990). Omeros. New York: Farrar, Straus and Giroux.

---------, D. (1987). The Arkansas Testament. London: Faber and Faber.

--------, D. (1986). Collected Poems 1948-1984. London: Faber and Faber.

---------, D. (1984). Midsummer. London: Faber and Faber.

Westphal, B. (2007). La Géocritique: Réel, fiction, espace. Paris: Minuit. Macmillan.

B. (2011). Geocriticism: Real and Fictional Spaces. Trans. Robert T. Tally Jr. London/New York: Palgrave 